\title{
Administering State Legislation: The Kirk and Witchcraft in Early Modern Scotland
}

Callum MacGlip MacDonald

This paper shall examine the relationship between the duties performed by the Royal court and the Calvinist Kirk (church) in early modern Scotland. Shortly following the Reformation, Scotland's civil governing body was officially separated from the duties and power of the kirk. In turn, the church was granted power to address all spiritual needs and requirements throughout the Lowlands of Scotland. Such developments may initially seem as the emergence of a secularized society, whereby the civil bodies of administration were detached from religious rule or order, and operated on their own accord. Before the state could create a secular body to uphold parliamentary law effectively, the vast network of kirk parishes throughout the country played a surprising, yet extremely effective role in upholding both state legislation and religious discipline in the localities of Lowland Scotland. Duties performed by the Post-Reformation Kirk for the local populace in conjunction with the church's relationship with the royal court and parliament, of which the latter was a relatively weak royal minority, are examined, along with the phenomenon and frequency of the early witch-hunts that occurred in Lowland Scotland. In doing so, this study carries contrasting evidence, including primary source material, to suggest that the beginnings of a secularized society had not yet emerged, at least in practice, and that the religious and civil administrations remained heavily interwoven after the Reformation.

Post-Reformation Scotland during the 16th century marks the beginning of the witch-hunts that would appear within the country for a one-hundred-and-fifty year period. With the abolishment of witchcraft legislation that occurred with Scotland's union with England in 1707, witch-hunts would cease. In the 16th and 17th centuries Scotland was characterized by stark cultural divisions between the Highlands and the Lowlands, and intermittent political, economic, and social upheaval that put Scotland's Royal authority and parliament in unstable positions of power. ${ }^{1}$ As the state developed rapidly, scholars have noted that the general patterns of escalated

\footnotetext{
${ }^{1}$ Goodare, Julian. "The Scottish witchcraft panic of 1597" in The Scottish Witch-hunt in Context. Manchester University Press, 2002. Print, 51; and Wormald, Jenny. Court, Kirk, and Community. Edward Arnold Publishers,
} 
witch-hunts have happened when the Royal court attempted to assert authority over the land as a means to consolidate power and regain political and religious control. ${ }^{2}$ Scotland's royal authority remained unstable due to weak royal minorities and monarchs who did not have a system of JP's (Justice of the Peace) in order to provide legislation administration and impose order and uniformity within the localities of the Lowlands, or the Highlands. ${ }^{3}$ Scholars argue that the royal court was decentralized towards local affairs and this allowed the relatively new Calvinist Church of Scotland to replace the duties of the former church after the Reformation. The Calvinist church was also building close ties to the state, administering religious guidance and secular administration to the localities. ${ }^{4}$ This paper shall closely examine the duties performed by the Post-Reformation Kirk for the local populace, in conjunction with the church's relationship with the royal court and parliament of Scotland. Before the state could create a secular body to uphold the parliamentary law in the evolving environment following the Reformation, the vast network of kirk parishes throughout the country played a surprising, yet extremely effective role in upholding both state legislation and religious discipline in the localities of Lowland Scotland.

The kirk was part of a hierarchy of the Church of Scotland that was at the lowest level of administration. ${ }^{5}$ The kirk held local courts, also known as 'kirk sessions', which were conducted by a board comprised of at least one minister and twelve lay-elders. The size of each parish dictated the number of individuals that could sit on each board, and some ministers were also in control of multiple parishes due to their varying size. ${ }^{6}$ The lay elders and ministers were typically elected by fellow lay elders and the ecclesiastical authority, the former being the most wealthy and politically powerful landowners within the community. ${ }^{7}$ These local parishes answered to the presbytery court, which was under the control of the General Assembly, a church court at the national level that was comprised of powerful clergymen, lairds, and burgesses who ran the church's affairs. ${ }^{8}$ Simply put, after the Reformation the Church hierarchy appeared to resemble a

1981. Print, 25; and Willumsen, Liv, Helene. Gow, Andrew (Ed). Witches of the North. Scotland and Finnmark. Brill, 2013. Print, 48.

${ }^{2}$ Goodare, Julian. "Witch Hunting and the Scottish state" in The Scottish Witch-hunt in Context, 123.

${ }^{3}$ The system of JP's would be created later in the late 17th century.Todd, Margo. The Culture of Protestantism in Early Modern Scotland. Yale University Press, 2002. Print, 409.

${ }^{4}$ Wormald, Jenny. Court, Kirk, and Community, 27.

${ }^{5}$ Every parish had a "kirk", and it is also the Scottish term for a church.

${ }^{6}$ McCallum, John. Reforming the Scottish Parish. Ashgate Publishing Ltd, 2010. Print, 15, 16.

${ }^{7}$ Todd, Margo (Ed). The Perth Session Books 1577-1590. The Boydell Press, 2008. Print, 3.

${ }^{8}$ Wormald, Jenny. "Bloodfeud, Kindred and Government in Early Modern Scotland" in Past \& Present, No. 87 (May, 1980), pp. 54-97. Oxford University Press. URL: http://www.jstor.org/stable/650566 .Accessed: 15-11-2015 18:19 UTC, 94. 
separate religious department that administered ecclesiastical matters and answered to the Scottish Parliament and central secular courts under the king.

In the kirk sessions, ministers, laymen and elders on the session boards met weekly, as often as four times a week (in large urbanized areas), in order to deal with matters of ecclesiastical administration and moral discipline within their community. ${ }^{10}$ Scholar Margo Todd notes that this was a considerable burden to the men who ran farms or businesses, as absence from a session usually resulted in a fine, but kirk records indicate that a low rate of men declined the responsibility. ${ }^{11}$ This suggests the position carried considerable obligations, but also possible benefits and status within a community. During periods of instability and weakness amongst the royal authorities, the kirks and parish ministers were crucial for administering both secular rule of law and religious discipline; connecting local communities with the higher authorities. From the kirks through to the General Assembly, these religious courts maintained a centralized system that had direct contact with the King, parliament, and the local population. The kirk may have been the largest estate in Scotland; however, it was unable to persuade noblemen to follow its strict agenda of moral discipline like the majority of the local parishioners - unless the nobles required the kirk's support for political means. ${ }^{12}$ As a result, the kirks had networks within the religious and the secular realms even though it may have lacked the means to enforce its disciplinary code in the face of more powerful and traditional interests, like the high nobility and the crown. It also had to follow any legislation enacted by the crown and the Privy Council.

By providing more than religious services and instruction to the community, the kirk also became a disciplinary institution. The parish ministers were able to preach their doctrine to the illiterate and in a vernacular the people understood, as Latin was no longer spoken in sermons. In order to maintain the doctrine and attendance at the Sabbath, the kirk was able to punish and try those who had committed moral offences. ${ }^{13}$ Such religious crimes included missing the Sabbath (absence from the Sunday kirk service), fornication, adultery, excommunication and slandering. The guilty were tried by the kirk sessions and received punishment when they had repented. ${ }^{14}$ Typically, the guilty person(s) would perform repentance on their knees front of the whole parish, a ritual where one was humbled before God and "with [their] own mouth [damn] [their] own impiety". ${ }^{15}$ Punishment would range from providing poor relief, fines (which went to the

\footnotetext{
${ }^{9}$ Goodare, Julian. The Government of Scotland 1560-1625. Oxford University Press, 2004. Print, 192.

${ }^{10}$ Todd, Margo. The Culture of Protestantism in Early Modern Scotland, 9, 10.

${ }^{11}$ Todd, Margo. The Culture of Protestantism in Early Modern Scotland, 10.

${ }^{12}$ Graham, Michael. "Equality before the Kirk? Church Discipline and the Elite in Reformation-Era Scotland" in Archiv für Reformationsgeschichte, Jahrgang 84, 1993. Hubert \& Co., Germany. Print, 295.

${ }^{13}$ Goodare, Julian. The Government of Scotland 1560-1625, 175.

${ }^{14}$ Todd, Margo. The Culture of Protestantism in Early Modern Scotland, 161.

${ }^{15}$ Ibid, 169 \& Todd, Margo (Ed). The Perth Session Books 1577-1590, 277.
} 
church's poor-relief fund or kirk upkeep), banishment, revocation of certain civil rights, or death. The agreement of suitable punishment depended on the severity of the crime. ${ }^{16}$ In addition, ministers emphasized the notion of "collective sin"; if someone had committed a religious crime it was not just the individual who was at fault, but the entire community for letting the act occur. ${ }^{17}$ This strengthened the community's conformity where fellow villagers attempted to prevent their neighbours from committing crimes, or reported them to the minister, thus keeping the majority of the community under the watch and ward of the kirk. ${ }^{18}$

Michael Graham argues that the kirk sessions valued the obedience of the local elite differently than that of the general population: the general parishioner was required to contain sexual activities within a lawful marriage, keep the Sabbath and adhere to peaceful habits. Local elites were expected to do the same, although the kirk overlooked sexual offences that were not notorious, partly because illegitimate children of wealthy landowners were unlikely to rely on the kirk's poor relief funds and the landowners were expected to lead the community by example. Commoners' political and religious orthodoxy however, was regularly under scrutiny and deviations remained a serious matter that required intervention and correction by the kirk. ${ }^{19}$ Furthermore, Michael Graham has composed data from kirk session minutes that belonged to eight different kirk parishes in the 16th century. Although he gives a precise number of cases, Graham cautions that his data is a low estimate, as many records remain missing or destroyed and missing details of identification of persons in the session books should be approached critically and cautiously. However, from a general analysis of the 4,594 cases listed, 339 (seven percent) of the accused wrongdoers were identified as nobles, lairds, and burgesses (in burgh parishes), along with some persons being elders or deacons of the kirk themselves. ${ }^{20}$ From the data, those of a somewhat higher social standing were rarely prosecuted for moral offences. Parishioners accounted for the majority of individuals that required moral discipline. Overall, the varied social hierarchy was expected to follow a moral example set by the kirk. As a result, the data suggests that the kirk courts were able to cut across the traditional social hierarchy, as the nobility were not wholly excluded from disciplinary punishment for moral offences. Furthermore, these nobles were tried by a session composed of social inferiors of lay elders and ministers.

\footnotetext{
${ }^{16}$ Larner, Christina. Enemies of God. Birlinn, 2000. Print, 56; and Todd, Margo (Ed). The Perth Session Books 1577-1590, 432.

${ }^{17}$ Todd, Margo (Ed). The Perth Session Books 1577-1590, 174.

18 Ibid, 31.

${ }^{19}$ Graham, Michael. "Equality before the Kirk? Church Discipline and the Elite in Reformation-Era Scotland", 298.

${ }^{20}$ Ibid, 296.

${ }^{21}$ Wormald, Jenny. "Bloodfeud, Kindred and Government in Early Modern Scotland”, 94.
} 
Fortunately for contemporary scholars, since the 16th century, kirk sessions recorded the minutes of almost each and every session that took place. This was partly for the kirk session's administration over a parish to be accessible to the higher authorities of the presbytery - if a complicated religious case appeared in the parish it could be forwarded from the kirk sessions to the presbytery court. ${ }^{22}$ The method of recording session minutes is said to have evolved from the secular minutes of the bailie courts and town councils, which is interesting to note, as kirks operated in a similar fashion when administering civil and religious trials and punishments. Although records from each parish have various gaps and sessions lost through time, substantial works remain and give some degree of insight to the issues the kirk sessions dealt with on a weekly basis. ${ }^{24}$ One recurring issue from the session records is the considerable difficulty the kirk had with the persistence of pre-Christian and Catholic festivities like St. Obert's and Corpus Christi Day celebrations, along with spring and summer solstice and Midsummer bonfire nights, which persisted long after the Reformation. In continuing such festivities people risked punishment by the kirk sessions, yet the traditions were kept alive - the kirk never managed to extinguish the latter of such festivals. ${ }^{25}$

While the kirk was heavily involved with enforcing Reformed doctrine within its parish, it also administered civil justice. ${ }^{26}$ The Black Acts of 1584 asserted crown authority over the church: church courts were brought under parliamentary sanction, and the Golden Act of 1592 that shortly followed transferred royal supremacy from the episcopacy to the presbytery. ${ }^{27}$ Thus, church measures were now subordinate acts of parliament and the local sheriff and bailie courts. These secularized courts of the legal administration in Scotland were below the Privy Council and operated on local levels in large towns and cities.

Due to this legislation, local offenders were initially tried in front of a kirk session. If proven guilty, the kirk elders passed the offender to the civil authorities such as the local bailie court. ${ }^{28}$ The civil authorities also helped the new church impose religious discipline when the central judiciary of the state made a number of moral offences dual crimes (both religious and state

\footnotetext{
${ }^{22}$ Todd, Margo (Ed). The Perth Session Books 1577-1590, 3; and Graham, Michael. "Equality before the Kirk? Church Discipline and the Elite in Reformation-Era Scotland", 305.

${ }^{23}$ Todd, Margo (Ed). The Perth Session Books 1577-1590, 6.

${ }^{24} \mathrm{Ibid}, 5$.

${ }^{25} \mathrm{Ibid}, 62,108$ - on this latter page, a perfect example of kirk discipline on those who were caught in the "mischievous acts" is described in full detail; and Todd, Margo. The Culture of Protestantism in Early Modern Scotland, 192, 193.

${ }^{26}$ Goodare, Julian. The Government of Scotland 1560-1625, 178.

${ }^{27}$ Ibid, 202.

${ }^{28} \mathrm{Ibid}, 86$.
} 
offences). In 1563, witchcraft became a dual crime due to maleficium and diabolism . ${ }^{29}$ Fornication followed in 1567, Sabbath breaking in 1579, and intoxication in 1617. By 1572, those excommunicated by the church were immediately outlawed by the state, which also prevented an excommunicated individual from holding any office or acting as a witness. Beginning in 1609, they were further banned from receiving income from lands and rents, which may help explain the high lay attendance and participation within the kirk sessions during the time this law was passed. ${ }^{30}$

The transition to dual crimes suggests that the court of judiciary and the church courts did not operate entirely separately. The Privy Council may appear to be secular due to the church handling religious matters (which was overseen by the Privy Council following the Black Acts) while parliament, the judiciary court, and the royal court appeared to handle secular affairs of the state. The religious laws that were incorporated within the secular realm of criminal offences however, also became subject to the civil power of the crown and parliament. As a result, the kirk became useful as another body to enforce the government's authority. ${ }^{31}$ The biblical offences that were religious crimes also became statutory crimes and were punished by both the state and the church. The appropriation of biblical wrongdoing into the secular realm is further demonstrated when usury became a dual offence in $1610 .^{32}$ While trials in the court of judiciary in Edinburgh were expensive, local kirk courts were cheap: the only monetary loss for a minor offense was the fine that accompanied the crime. ${ }^{33}$ As a result, it was more common for parishioners to take any case of civil or religious matters before the kirk session instead of the civil authorities. ${ }^{34}$ Moreover, in certain parishes that were in close proximity to the burgh courts in areas like St. Andrews, local cooperation between the burgh and kirk courts to try ecclesiastical and civil punishment within one court was not uncommon either. ${ }^{35}$ While the two branches of authority combined and cooperated in many cases, in the higher echelons, the church's influence can also be examined.

The church's desires to uphold moral discipline and civil legislation through the kirk is clear upon examination of the acts and proceedings of the General Assembly of Scotland in May of 1586:

\footnotetext{
${ }^{29}$ Maleficium was regarded to be a form of harmful magic and thus a state crime as it could harm persons, and diabolism was also tied to witchcraft. This latter component was the religious aspect of the crime, as kirk ministers did not tolerate the worship of the Devil.

${ }^{30}$ Willumsen, Liv, Helene. Gow, Andrew (Ed). Witches of the North. Scotland and Finnmark, 55, 56.

${ }^{31}$ Goodare, Julian. The Government of Scotland 1560-1625, 197, 209.

${ }^{32}$ Ibid, p 210.

33 Todd, Margo. The Culture of Protestantism in Early Modern Scotland, 230.

${ }^{34}$ Ibid, 230.

${ }^{35}$ Goodare, Julian. The Government of Scotland 1560-1625, 207.
} 
"Matters to be intreattit in the Presbyteries...to inquyre dilligentle of naughtie and vngodlie persons...His Majestie aggried vnto this syst article after this manner: It hes power to excomminicat the obstinat...Faults to be censured in the Prebyterie: Heresie, papistre, apostasie, idoatrie, witcraft, consulters with witches... Ministers and Sessioun, they have power and jurisdiction of their awin congregation in matters ecclesiasticall, to take ordour therewith; and things they cannot decyde, to bring them to the Presbyterie." ${ }^{36}$

This excerpt illustrates the transferral of complicated cases from the kirk to the Presbytery as previously mentioned. It also discusses the handling of religious crimes along with dual offences, witchcraft in particular. This passage also indicates the king's legislation being put into effect by the presbytery and the direct communication between the church and obedience to crown rule.

At a local level, session records occasionally record the names of individuals that reported offenders, who were not always the elders or kirk officers. Ordinary parishioners took up a moral watch on their own in order to prevent the community from acts of sin, as previously mentioned, ministers stressed that collective sin could be caused by one person. While local zeal was helpful, a common entry of the session's weekly habits was the appointment of 'visitors' or 'searchers' on the Sabbath. These were elders were authorized to enter and search people's homes in order to find peoples that were absent from the Sunday service. The former would also collect fines from the absentees on the spot. Occasionally, such 'searchers' took along a bailie to enforce the civil and ecclesiastical authority to enter and search property and dwellings. ${ }^{37}$ The kirk and tolbooth ${ }^{38}$ were also seen as the most important buildings within the town, and further suggests the close co-operation of local kirk elders and civil court bailies when administering the religious and civil laws by creating an importance of local law and order through these buildings. 39

By increasing the number of dual offences and putting the kirk under the crown legislation, the secular courts strengthened the control kirk ministers had over the civil rights and moral discipline of their parish, as shown by the example of the elder 'searchers'. ${ }^{40}$ With this approval from the crown court, the kirk alone tried both civil and religious crimes and administered punishment without requesting permission from the civil authorities as had been done before. It

\footnotetext{
${ }^{36}$ Acts and Proceedings of the General Assemblies of the Kirk of Scotland, 1560-1618. Originally published by [s.n.], Edinburgh, 1839. Online Source: http://www.british-history.ac.uk/churCh-scotland-records/Acts-pro ceedings/1560-1618/pp645-684 DOI: 1/11/2015.

${ }^{37}$ Todd, Margo. The Culture of Protestantism in Early Modern Scotland, 32, 33.

${ }^{38}$ The tolbooth was a building where the bailie's court met and criminals were gaoled.

${ }^{39}$ Todd, Margo (Ed). The Perth Session Books 1577-1590, 13.

${ }^{40}$ Goodare, Julian. The Government of Scotland 1560-1625, 184.
} 
should be noted that the execution of sinners outside of the witch-hunt periods was quite rare, and it was more common for dual crimes. For example, in January 1585 two individuals were hanged at Perth for committing 'notorious' adultery in accordance with the parliamentary statute regarding their crime and punishment. This case also occurred during a famine that had ravaged Perth, when the kirk session had stated that a close relationship existed between the ravages of the plague and the sin of adultery. ${ }^{41}$ Along with visible penitential performances during times of natural disaster, the church periodically partook in acts of repentance in hopes of appeasing the wrath of God: " the penitential rite was the place where the sacred and profane came together...Individual repentance sought divine forgiveness...corporate repentance in a communal fast addressed the cosmic power that used snow and wind, disease and hunger to condemn sin". ${ }^{2}$ Through these rituals, many parishioners believed they could avert 'spectacles of his wrath' during times of natural disaster and hardship, and this is indicative of large-scale community involvement under the kirk's leadership.

Episodes like these enthusiastically engaged the kirk with purifying the community of sin in a ritualistic manner; the reformed kirk sessions also provided a parochial mechanism towards conflict resolution between members of the community. The kirk minutes allow one to get a glimpse of exactly how this mechanism functioned, for the system was implemented relatively quickly due to the popular support for the kirk's capacity to encourage peacemaking and de-escalate the usual violence that would typically follow feuds. ${ }^{43}$ The kirk provided a beneficial impact upon local parishes, as it encouraged reconciling with enemies and resorting to harmony when feuds and other violence could emerge. In the case of penitential rites, the elders did not completely avoid Catholic traditions and rituals of reconciliation, as they acted again on the general principle that a new theology and service would be accepted more easily with the administering of practical tradition. ${ }^{44}$ Examining the Stirling Presbytery records, the pragmatic handling of feuds can be seen in one example in April 1587: a "dedlie feud that remain betuix that Grahamis in Mentayth and him (a Thomas Murdochsone)", was handled by having the individual at the centre of the feud, Thomas, give a public repentance in the kirk on the following Sunday and in the interim he had to avoid coming to all synod assemblies until further notice, as the 'Grahamis' in Mentayth would be present there.

The elders gave Thomas approval to be absent from these synod meetings due to the possibility that the raging feud could escalate into further violence if the two individuals were in close proximity with each other. To enforce a separation between the two parties and allow the affair to settle down, Thomas would also face punishment by the kirk and presbytery court if he

\footnotetext{
${ }^{41}$ Todd, Margo (Ed). The Perth Session Books 1577-1590, 44, 45.

${ }^{42}$ Todd, Margo. The Culture of Protestantism in Early Modern Scotland, 180.

${ }^{43} \mathrm{Ibid}, 231$

${ }^{44}$ Ibid, 232.
} 
disobeyed the orders. ${ }^{45}$ The kirk sessions were able to play an active role in pre-emptively curbing local violence before it occurred, or in some cases lessen the amount of violence that could potentially occur. The frequency of kirk sessions in the parishes were beneficial in addressing feuds and events of immediacy, in comparison to the considerable wait between court sessions that would occur if a violent feud case were put before the civil court. If many feud cases were not addressed quickly they were likely to escalate into violent acts before the original feud could be addressed in a civil court. ${ }^{46}$ As a result, the kirk willingly began mitigating cases that would have normally been under separate civil jurisdiction and in secular courts.

Whilst addressing local violence and kirk intervention after highlighting kirk functions and duties, the legislative and prosecution patterns carried out during witchcraft hunts in early modern Scotland shall be examined. Michael Wasser argues that the valleys of inactivity between the series of explosive prosecutions of witches that occurred in Lowland Scotland were curtailed by the further centralization of the prosecution progress under the crown. The critical approaches developed by state judges towards case evidence played a major role as local kirk sessions became overzealous in prosecuting witches, which soon needed to be restricted by the central government. $^{47}$ This paper shall demonstrate that there was more to the escalation and suppression of the witch prosecutions than just the power of the state clamping down on the local kirks. Witchcraft had been linked to the Devil from an early period (the Witchcraft Act of 1563). Before the first major witch persecutions that occurred in Scotland in the 1590s, many Lowland parishes, especially in rural areas, did not fully associate magic with the Devil or with evil, as many local beliefs in the supernatural and fairies existed. However, the kirk adamantly stressed that any type of sorcery committed outside the context of the church was evil. ${ }^{48}$ Although there were kirk session cases where people were accused of witchcraft before the 1590 s, very few cases resulted in the defendant being found guilty. In the Perth session records it was more common for those who accused someone of being a witch to be fined for slandering. ${ }^{49}$ In November of 1589, the Perth kirk session was to "declair quidder it was trew that [first name illegible] Gudell, spouse to Richart Watson was ane witsche as Jhon Watson allegit or quhat evil likliheid thai saw in hir...scho was ane honest puir woman... the ministers and elders ordains the

\footnotetext{
${ }^{45}$ Kirk, James (Ed). Stirling Presbytery Records 1581- 1587. Edinburgh, Clark Constable LTD, 1981. Print, 246, 245.

${ }^{46}$ Todd, Margo. The Culture of Protestantism in Early Modern Scotland, 229, 233.

${ }^{47}$ Ibid, 229; and Wasser, Michael. "The Privy Council and the Witches: The Curtailment of Witchcraft Prosecutions in Scotland, 1597-1628”. Scottish Historical Review, Volume I.XXXII, 1: No.213: April 2003, 20.

${ }^{48}$ Larner, Christina. Enemies of God. 9, 198.

${ }^{49}$ Slandering, also known as 'flyting', was a term used when the accusers of any given crime would be found to have lied, or, when an individual was using foul language towards another for no good reason, such as needless cursing and using the Lord's name in vain. In the example above, the accuser was deemed to have lied and is thus labelled "a slanderer" by the session.
} 
act of sklander (slander) to be put in execution against the said Jhon Watson". ${ }^{50}$ In June 1581, Cristan Livingston was tried by the kirk session and confessed to be a "deceiver of the pepil" (the ability of second sight, or magical healing). ${ }^{51}$ She was then transferred to the hands of the civil court bailies "to suffer and inquest". ${ }^{52}$ Although this accused witch was probably tortured by the kirk session before her confession was given, the Witchcraft Act of 1563 placed the cases of witchcraft to be pursued by the secular legal courts of the Privy Council and its lower civil courts. As a result, the kirk functioned as the religious body that would obtain the confessions of the accused before passing them to the civil authorities. ${ }^{53}$

In 1591 and 1597, Lowland Scotland experienced its first two major witch-hunts. Christina Larner attributes the initial spikes of panic to the arrival of educated witch theory in Scotland from Europe in 1591, which permeated from the royal court through the social hierarchy. ${ }^{54}$ King James VI would soon publish his book of Daemonologie in 1597, during another witch panic. In December 1589, a Violet Brown was accused of "turning the riddell" and going against the word of God, which was seen as a diabolical crime. ${ }^{55}$ However in this particular case, though minor offences of sorcery were punished, Brown was acquitted by the kirk session. Instead, the merchant, the elder and county sheriff who had brought her to court were fined for slandering, illustrating the earlier method of handling accusations of witchcraft. ${ }^{56}$ This form of fortune telling was trivial within the Perth parish, but by 1597, King James VI stated his personal disturbance with this particular type of sorcery to supposedly be linked with that of the Devil's. ${ }^{57}$ While King James VI propagated his theories on magic and evil within Scotland, these educated views spread from the educated elite, and through the close intertwinement of the Church General Assembly and the Privy Council, the plan to uproot evil sorcery from God's land then reached the local parish ministers. From the ministers it was spread to the public through the word of the kirk. ${ }^{58}$

\footnotetext{
${ }^{50}$ Todd, Margo (Ed). The Perth Session Books 1577-1590, 431, 432.

${ }^{51}$ Ibid, 432, 432.

${ }^{52}$ Ibid, 187.

${ }^{53}$ Wasser, Michael. "The Privy Council and the Witches: The Curtailment of Witchcraft Prosecutions in Scotland, 1597-1628", 22.

${ }^{54}$ Larner, Christina. Enemies of God, 198.

55 "Turning the Riddell" is a phrase that means to tell fortunes. Todd, Margo (Ed). The Perth Session Books 1577-1590, 434, 435.

${ }^{56}$ Larner, Christina. Enemies of God, 200; and Todd, Margo (Ed). The Perth Session Books 1577-1590, 435.

${ }^{57}$ King James, I of England and VI of Scotland. Daemonologie (1597). Harrison, G. B. (Ed). London, John Lane Publishers, 1924. Print, p 12.

${ }^{58}$ Todd, Margo. The Culture of Protestantism in Early Modern Scotland, 49; and Willumsen, Liv, Helene. Gow, Andrew (Ed). Witches of the North. Scotland and Finnmark, 90.
} 
As Liv Willumsen demonstrates, there is a relationship between times when the demonological element of 'sorcery' was stressed and an increase in witch accusations and guilty prosecutions. As illustrated from primary sources, the treatment of local cases of sorcery before the1590s suggests a degree of kirk and civil leniency when compared to the kirk torture and local civil authorities' $90 \%$ execution rate of the witch cases that occurred during the witch panic periods. ${ }^{60}$ In the witch-hunt period of 1597 , Willumsen calculates that $80.4 \%$ of all witchcraft trials were held within local courts with judicial commissions that had been issued to the local civil magistrates by the Privy Council. ${ }^{61}$ The kirk sessions' methods of torture to obtain initial confessions from the local parishioners (who also made up the majority of local court cases) were undoubtedly brutal. However, if found guilty of witchcraft the accused was passed to the local bailie court and then officially tried for maleficium under state law. ${ }^{62}$ In order for the kirk to proceed and give a case of witchcraft to the local civil court to be tried, the civil court had to obtain a commission of judiciary, which was provided by the secular Privy Council. ${ }^{63}$ Therefore, in order for a witch to be prosecuted locally and executed by the local civil authorities, the bailie courts required a general or specific commission from the Privy Council. Without a judicial commission the local courts were not allowed to try and execute witches for they had to be tried in the central court of judiciary in Edinburgh, unless specified through the use of a commission. 64

The decline of enthusiasm in the witch-hunts during the $1590 \mathrm{~s}$ period has been credited to miscarriages of justice within the civil courts. The procedures to prosecute witches slowly became restricted by the higher central crown authorities in order to curb the number of witch trials based on flimsy evidence, and the execution of innocents. ${ }^{65}$ While this suggests logical reasoning behind stopping the prosecutions, the Privy Council still administered commissions to local courts, but less frequently than before. ${ }^{66}$ The enthusiasm to root out witchery began in earnest through the high civil courts and educated elite, although the change in attitude towards the local prosecutions and trials would also begin at the state's Privy Council level, which would use its power to control the local civil and kirk courts. This relationship appears to be suggested when examining the Privy Council's encouragement of the witch-panics and their trials, resulting in many executions for sorcery. The reverse is also seen, when attitudes in the Privy Council

\footnotetext{
${ }^{59}$ Willumsen, Liv, Helene. Gow, Andrew (Ed). Witches of the North. Scotland and Finnmark, 93.

${ }^{60}$ Levack, Brian, P. "The decline and end of Scottish witch-hunting” in The Scottish Witch-hunt in Context (Ed) Goodare, Julian, 171.

${ }^{61}$ Willumsen, Liv, Helene. Gow, Andrew (Ed). Witches of the North. Scotland and Finnmark, $70,71$.

${ }^{62}$ Larner, Christina. Enemies of God, 114.

${ }^{63}$ Goodare, Julian. "Witch Hunting and the Scottish state" in The Scottish Witch-hunt in Context, 142.

${ }^{64}$ Goodare, Julian. "Introduction" in The Scottish Witch-hunt in Context, 6.

${ }^{65}$ Goodare, Julian. "Witch Hunting and the Scottish state" in The Scottish Witch-hunt in Context, 142.

${ }^{66}$ Goodare, Julian. The Government of Scotland 1560-1625, 67.
} 
change towards sorcery and the killing of innocents, which then resulted in a display of secular power over the religious courts and kirks to prevent further large scale confessions of witchcraft.

This paper suggests a relationship within the central crown authorities and the Presbyterian Church following the Reformation in Scotland. While there may have been impetus to decrease witchcraft trials and executions towards the end of the 1590-1591 and 1596-1597 witch panics, the crown kept legislation in place that allowed local civil courts to try offenders if bailies requested a commission. During the panics the endeavours to make the parishes a godly society would be upheld by the local kirk sessions, as they tortured and provided the majority of local offenders who would be later tried. During the panic periods accused witches were also far more likely to be executed. The church system may have outwardly appeared to function without delving into secular affairs while the state oversaw civil and non-religious duties. However, by closely examining the functions of the local kirk sessions and parishes, the methods used by the kirk to discipline the community, and how the kirk aided civil authorities, suggests otherwise. The interests of the church and state were not divided. There was no secular realm of civil authority, as the royal court and Privy Council enforced religious persecution in the form of state legislation through dual crimes, such as witchcraft. Furthermore, the kirk operated as a civil and religious institution, providing religious guidance and discipline whilst maintaining civil order on the ground (as demonstrated with the handling of feuds), through preaching and punishment. The kirk session was a significant body within the parish; it ultimately supplied local civil courts with individuals who had committed dual or civil crimes, particularly those involved with witchcraft during the panic periods.

Through the kirk session system, the new church became closely meshed with the secular state councils and courts, joining a decentralized state in a turbulent period, with a centralized religious institution that gave power to local laymen and ministers within parishes. They effectively conducted control, administered civil and religious duties and created a distinct Scottish Protestant culture following the Reformation. From these findings it is clear that as early modern Scotland was developing rapidly, through civil and religious institutions, such institutions remained a connected body, with civil and religious affairs interwoven through various levels of society. 


\section{Bibliography}

Acts and Proceedings of the General Assemblies of the Kirk of Scotland, 1560-1618. Originally published by [s.n.], Edinburgh, 1839. Online Source: http://www.british-history.ac. k/church-scotland-records/acts-proceedings/1560-1618/pp645-684 DOI: 1/11/2015.

Goodare, Julian. The Government of Scotland 1560-1625. Oxford University Press, 2004. Print.

Goodare, Julian (ed). The Scottish Witch-hunt in Context. Manchester University Press, 2002. Print.

Graham, Michael. "Equality before the Kirk? Church Discipline and the Elite in Reformation-Era Scotland" in Archiv für Reformationsgeschichte, Jahrgang 84, 1993. Hubert \& Co., Germany. Print.

Kirk, James (Ed). Stirling Presbytery Records 1581- 1587. Edinburgh, Clark Constable LTD, 1981. Print.

Larner, Christina. Enemies of God. Birlinn, 2000. Print.

Levack, Brian, P. "The decline and end of Scottish witch-hunting” in The Scottish Witch-hunt in Context, Goodare, Julian (ed). Manchester University Press, 2002. Print.

McCallum, John. Reforming the Scottish Parish. Ashgate Publishing Ltd, 2010. Print.

Todd, Margo. The Culture of Protestantism in Early Modern Scotland. Yale University Press, 2002. Print.

Todd, Margo (Ed). The Perth Session Books 1577-1590. The Boydell Press, 2008. Print.

Stewart, King James, I of England and VI of Scotland. Daemonologie (1597). Harrison, G. B. (ed). London, John Lane Publishers, 1924. Print.

Wasser, Michael. "The Privy Council and the Witches: The Curtailment of Witchcraft Prosecutions in Scotland, 1597-1628" in Scottish Historical Review, Volume I.XXXII, 1: No.213: April 2003, 20 - 46. Print.

Willumsen, Liv, Helene. Gow, Andrew (ed). Witches of the North. Scotland and Finnmark. Brill, 2013. Print.

Wormald, Jenny. Court, Kirk, and Community. Edward Arnold Publishers, 1981. Print.

Wormald, Jenny. "Bloodfeud, Kindred and Government in Early Modern Scotland" in Past \& Present, No. 87 (May, 1980), pp. 54-97. Oxford University Press. URL: http://www.jstor.org/stable/650566 .Accessed: 15-11-2015 18:19 UTC 